\title{
The role of the state in ensuring food import substitution at the regional level in a pandemic
}

\author{
Tatyana Solovyova, Danil Zyukin \\ Kursk State Agricultural Academy, Russia
}

\begin{abstract}
The study analyzes the aspects that determine the change in the role of the state and the form of its impact on the agricultural sector in the context of the impact of the pandemic on all socio-economic processes in the country. The article reveals the importance of implementing the import substitution program from social and economic positions for Russia. A complex of adverse consequences brought by the pandemic to the public life and economy of the country is given, which determines the change in the role of the state in matters of regulation and direct financial support of agricultural production. The article discusses the advisability of using "helicopter money" as a way to help the population in difficult social conditions and at the same time as a way to stimulate effective demand for essential domestic products, including food products. In the context of a pandemic, the necessity of payments to support direct agricultural producers to maintain their financial stability is substantiated, the calculation of which is recommended to be tied to the arable land area and livestock population. The study provides a list of basic principles that are recommended to be applied when using instruments of direct financial support and regulation from the state. It is important to ensure not only the survival of agribusiness in the current conditions, but also to create opportunities for maintaining investment activity in the implementation of large projects, as well as to ensure the maintenance of the level of intensification in the current production cycle.
\end{abstract}

\section{Introduction}

Recently, the world has been seized by a viral threat of a huge scale, which affects not only human health, but is also a catalyst for the global economic crisis. Many countries are faced with the need for significant socioeconomic changes, which resulted in the need to allocate a significant amount of financial resources to support their population and preserve their business. Russia is also a country in which the socio-economic situation has also changed significantly: a regime of self-isolation of citizens was declared, many small and medium-sized businesses temporarily suspended their activities. Under these conditions, the population faced a drop in income, and business suffered a decrease in effective demand and limited factors of production. The complexity of the situation in the Russian economy is complemented by a significant drop in prices for energy resources, the extraction of which is traditionally a backbone industry in the country and the main source of budget revenues.

In such conditions, the Russian government should offer a significantly larger amount of financial support and expand the list of state and economic regulation instruments capable of leveling or smoothing out the impact of the crisis on business and the population. Moreover, support should go not only in areas that are suffering more than others right now, but also in the backbone industries, on the state of which the long-term development of Russia and its economic security depend. You can get a lot of information in the news blocks of the main media and Internet sources about the problems experienced by representatives of the entertainment, catering, logistics, retail sector, who are quite media-aware, and their owners are more socially active, while the problems of farmers behind the general noise against this background most citizens feel much weaker. This is a big threat to the socio-economic situation of the country in the near future, if the sowing campaign fails, which is facilitated by a whole list of unfavorable factors and reasons. The consequences of a bad year, as history shows, have always had a critical impact on the state of society and the position of power; therefore, the state should in no case allow the failure of results in agriculture, which, although not as active as it was anticipated to do, has been developing steadily in recent years, and Russia is gradually transforming from a net importer into a net exporter.

Therefore, the issues and problems of the implementation of import substitution in the agricultural sector are relevant in the context of providing the population with food. The analysis of the provisions of import substitution in the food issue is closely linked with the regional economic policy in relation to the regions of Russia specializing in agricultural production. The state of the economy of the agricultural sector in these regions determines the further implementation of import substitution of food on a national scale and at the same time is the basis of economic stability or a driver

\footnotetext{
* Corresponding author: solovyeva.kgsha@gmail.com
} 
for activating local economic processes. This explains the need to adapt the mechanism of state regulation to the peculiarities and tasks of agricultural production at the regional level in the current socio-economic conditions.

\section{Results and Discussion}

\subsection{Problems that the pandemic brought to agricultural production}

Global difficulties in the oil market and the pandemic exacerbate the impact of existing difficulties on the development of the Russian agro-industrial complex. First, the continued high dependence of the Russian economy on imports is also characteristic of agriculture, especially in the context of the use of genetic selection achievements, agricultural machinery and equipment. Therefore, the next wave of ruble devaluation, provoked by the collapse of oil prices, will inevitably lead to an increase in production costs, although to a lesser extent than in 2015.

Second, difficulties with logistics due to restrictions on the movement and work of business will inevitably affect the territorial-sectoral division of labor in agroindustrial production and the food supply of regions, the level of self-sufficiency of which is significantly different due to the differences in natural, economic and social conditions [1]. The second reason affects the possibility of promptly repairing and replacing spare parts for agricultural machinery and production equipment, since the logistics communication between the countries is also limited, which is complemented by the rise in the cost of imports due to the depreciation of the ruble.

Third, the already existing high debt load of the agricultural business, while maintaining strict current lending conditions, limits the possibilities of attracting credit resources both to ensure the implementation of new projects and to form working stocks, which will certainly be needed in the current situation. At the same time, the easing of monetary policy has not yet taken place and is hardly foreseen. It is because of this that the demand for and the need to use such an instrument of state support as subsidizing the interest rate, implemented mainly for investment projects, for example, in animal husbandry, is explained, without which they significantly increase the payback period. The implementation of the concessional lending program for small and medium-sized businesses assumes an interest rate of up to $8.5 \%$. This is still much higher than the percentage at which European and American farmers receive loans under normal conditions. This fact clearly reflects the unfavorable financial conditions for the development of agribusiness in Russia, where state support is only compensatory in nature.

Fourth, the restriction in international trade amid a pandemic will not only lead to difficulties in providing the Russian market with imported products, but will slow down export processes, which in a number of areas of agricultural production are important incentives for further development and increase in production [2]. Russia is a major player in the world market of grains and oilseeds, provides its domestic needs in a number of areas of meat and sugar production, which forms the export potential here too, so limiting the export of products can have an extremely negative impact on their investment attractiveness [3]. For example, a quota of 7 million tons has already been introduced for the export of grain outside the EAEU until June 30, the task of which is to provide the domestic market with a sufficient volume of grain to meet the needs of animal husbandry and flour milling. Also, sunflower, soybeans, cereals and rye were subject to time restrictions. However, this, in principle, is not the best solution, since the structure of grain production in a number of regions is tailored specifically for export, which determines the threat of a decrease in the investment attractiveness of grain farming and a slowdown in the modernization of production and logistics infrastructure [4].

The threat of a grain shortage in the Russian market can be solved by prompt regulation of domestic prices, which as of early 2020 are not significantly inferior to world prices, and their leveling is expected, even despite the devaluation of the ruble. In addition, the option of reexport through the EAEU countries is more than realistic, i.e. in fact, there will be a decrease in the competitiveness of Russian grain, and the budget will receive less taxes.

Fifth, one of the trends in the development of agribusiness in Russia is its consolidation and the increasing role of large agricultural holdings. Due to economies of scale, large business has a number of preferences, but at the same time, enlargement also brings the need to involve additional working capital in order to maintain the required level of intensification. In the context of rising prices for industrial goods and the inaccessibility of short-term loans to maintain business activity, it becomes extremely problematic to achieve this, which implies a decrease in production and economic results. The experience of the period 20152016, the results of which were most affected by inflation due to the collapse of the ruble exchange rate, testifies that the cluster of the largest organizations showed a lower level of production and economic indicators of the cultivation of agricultural crops, as compared to the average level in the region, and only exceeding the indicators of small farms with arable land area less than 1 thousand ha.

Sixth, the threat of mass infection of employees at enterprises where production processes are characterized by a concentration of personnel, for example, in the food industry and processing, livestock sub-complexes, has significantly increased. Infection cases can paralyze the work of an entire enterprise, and the business entity itself can become a platform for the transmission of the disease. In addition, agribusiness enterprises are mainly concentrated in rural areas, where the quality of medical care is unlikely to meet the standards to solve the problem of patients with coronavirus. Therefore, it is important to provide all employees of enterprises with protective equipment of the required level, and to send people who are at risk for medical reasons to work 
remotely with the preservation of wages. However, all this requires costs that the business does not want to bear and is far from always be capable of. The state should take on part of the risk, because the primary goal for business is to use all available factors of production to maximize profits, while finding the solution of social and epidemiological problems is not inherent in the very nature of business development and is borne by the state.

Seventh, in difficult financial conditions, a decrease in the intensification of production is inevitable, which for crop production, as shown by foreign experience [5], leads to an increase in the load on the basic natural potential of the soil with an inevitable negative impact. In Russia, in addition to this, for many years, the cultivation of agricultural crops was carried out with insufficient fertilization; crops were grown due to the natural indicators of the soil. In the last decade, the situation has changed and farmers began to actively and effectively use mineral fertilizers as a condition for intensification. However, new financial and economic conditions can return production to the past, so the state needs measures to support and protect land as the main factor in agricultural production.

There are a number of other factors and reasons that form threats to the development of the agro-industrial complex and reduce the stability of the agri-food market in Russia, which predetermines the need for a prompt government response to adjust the system of state and economic regulation of this sector of the economy.

\subsection{Principles of state regulation of agriculture that determine its effectiveness in a pandemic}

Analysis of the dynamics and structure of direct state support for agricultural production using the example of the region allows assessing the trends and showing the existing imbalances in favor of subsidizing the interest rate on loans, which, in fact, compensates for the shortcomings of the country's financial model and the excessively high interest on loans for the agricultural business. The improvement of the model and system of measures of state and economic regulation of the agrifood market is carried out on the basis of a number of fundamental principles:

- guaranteed financial support from the state and clarity in instruments, amounts and terms, so that business sector can plan its activities taking into account these funds;

- the effectiveness of regulation of the agri-food market and protection of the interests of direct agricultural producers and the population as the final consumer of food products;

- the complexity of regulation, which consists in a combination of instruments of state and economic regulation with direct financial support;

- the adequacy of the amount of direct financial support, the challenges facing and the expected losses of the business;

- regulation of the agri-food market and agricultural production should mainly follow stimulating methods, and not just compensate for the growth of prices, tariffs and interest on loans;

- wide availability of regulatory measures to agrarians and direct financial support, regardless of the form of ownership and the size of business.

\subsection{System of state regulation of agricultural production}

The system of measures of government influence on the functioning of the agri-food market includes both direct support and regulatory instruments. In domestic realities, the implementation of direct support measures is carried out through the allocation of subsidies, grants and compensations within the framework of federal and regional programs. At the same time, direct support is not fundamental for many areas of agricultural production. This is due to its structure, in which a significant share is accounted for by interest rate subsidies on loans, mainly investment loans. In general, the subsidizing mechanism can be called compensatory, since the funds allocated by the state are directed to compensate for the growth of production costs or tariffs, and also mitigate monetary policy that is unfavorable for the real sector of the economy.

In the context of the pandemic, many people and businesses have found themselves in difficult economic conditions, so direct financial support from the state seems extremely urgent. A reserve can be the transfer of responsibility to regulatory measures: freezing the tariffs of natural monopolies, reducing the excise tax in fuel for agrarians, freezing payments on bank loans for the period of a pandemic.

In traditional conditions, it is in any case advisable to leave direct government support, since such areas are limited by the WTO rules, are limited in accessibility and form the preconditions for the creation of corruption schemes, creating conditions for the growth of inflation. The concentration of direct financial support is logical and appropriate in the areas of innovation and $R \& D$ development, while in the form of subsidies and compensation, this can lead to imbalances in industry markets.

In a pandemic, direct financial support becomes necessary, as force majeure conditions arise, in which it is difficult for a business to fully function, but it is also necessary to provide organizational, industrial and socioeconomic protection of its employees. Its shape can be completely different, but in optimal terms it is possible to support farmers with reference to production capacity: for example, per 1 hectare of arable land for crop production areas; with reference to the livestock population for animal husbandry. The purpose and validity of such support measures is to ensure business activity of the agricultural business in difficult times for it, in order to provide the population with domestically produced food without loss in quality and growth in value, without endangering the prospects for long-term development.

Priorities among government measures to intensify import substitution should be given in favor of indirect 
impact through market regulation instruments. For example, by creating additional demand in the domestic market as an incentive to increase production or reorganize surplus. The peculiarity of the agrarian sector is that the final consumer is the entire population of the country, and not a certain part of it. Therefore, the provision of material assistance to every citizen of Russia will not only be a way to support families in difficult times, when many have lost income, but also to maintain demand for essential products, which include food.

This measure was actively used in economically developed countries to support the population during the active phase of the pandemic, but in Russia this measure had very limited application. This is largely due to the position of the Central Bank and the Ministry of Finance, which is based on Milton Friedman's experiment in the use of "helicopter money". In a liberal economic interpretation, this approach to money emission does not lead to a real increase in gross output, but stimulates inflation. In favorable conditions, such a position is justified, but in the situation in which many Russians found themselves during the period of self-isolation, such a comparison, in our opinion, is inappropriate. An example is the experience of the United States, where people with incomes below $\$ 75,000$ a year received a one-time aid in the amount of $\$ 1,200$. In the context of Russian realities, the allocation of benefits to lowincome families is not only a social obligation of the state in force majeure circumstances, but also acts as an indirect support for domestic manufacturers of essential products also supporting business. In the context of the development of agriculture and the provision of import substitution, supporting consumer demand for food is very relevant, since according to Rosstat alone, almost 20 million Russians are below the poverty line. Of course, this measure can be one-time, appropriate for conditions of social exclusion and a decrease in earning opportunities for the population. In systemic practice, such a measure of state support presupposes an appropriate mechanism for distributing money with a direct link to the peculiarities of the functioning of local agri-food markets.

Both under normal conditions and during the coronavirus threat, an effective mechanism for regulating the agricultural market is fundamentally important to ensure import substitution of food. It is important to provide optimal conditions for the restoration of the investment climate in the agricultural sector of the leading agrarian regions of the country as the basis for the further increase in agricultural production. In difficult social and economic conditions due to the pandemic, investing and continuing to increase production intensification can be facilitated by preferential fiscal and monetary policies in the form of tax preferences or credit incentives for projects aimed at enhancing food import substitution. Given the geography and climate of the country, one of the priorities should be greenhouse projects that ensure the production of vegetables in regions with unfavorable natural conditions, large projects for the introduction of meat and dairy complexes, as well as high-tech processing of agricultural raw materials. It is important to ensure the protection of the interests of direct producers of agricultural products.

\section{Conclusion}

Agricultural production is a priority sector of the country, since the food supply of the population directly depends on its condition. In the context of the coronavirus pandemic, all sectors of the Russian economy have suffered to one degree or another, and agriculture is no exception. In such a situation, in order to maintain productivity and implement import substitution in the future, it is very important to support farmers with direct and indirect measures in order to neutralize the influence of negative socio-economic factors. The study presents a number of global challenges that agricultural producers will face during and out of the pandemic. All this necessitates an increase in the role of the state in the development of agriculture and regulation of the agri-food market.

The article presents a system of principles that should be observed when implementing measures of state regulation and support of the agricultural sector in order to increase their efficiency and bring budgetary allocations to direct agricultural producers. Under the conditions, the authors consider it reasonable to increase direct financial support for agricultural producers, depending on their scale, linking the allocated funds with relative indicators: for example, per 1 ha of arable land or with reference to the livestock population.

In the context of the regime of restrictions due to the coronavirus, to support the welfare of the population, it is advisable to consider the allocation of "helicopter money" as a tool for simultaneously stimulating Russian entrepreneurs who provide the domestic market with domestic products. Of course, this is a one-time action that should be used in a particularly difficult period, for example, during self-isolation of citizens, when the incomes of a large share of the population are threateningly reduced and there is a risk of a threat not to provide themselves with essential products. This problem looks especially vivid against the background of a large percentage of the poor in Russia. And this measure could help to partially solve the problem of low-income families and support the demand for domestic agricultural products.

To ensure the further implementation of the import substitution program, it is important to maintain the impetus for the development of agriculture before the pandemic, therefore, in difficult economic conditions, it is necessary to more actively use the instruments of state regulation. In the short term, direct financial support is relevant, but in the long term, it is important to form an adaptive mechanism of state regulation to the new socioeconomic realities, which will be based on the strategic task of transitioning the domestic agro-industrial complex from import substitution to an export-oriented agrarian economy. 


\section{References}

1. A.I. Altukhov Bulletin of the Kursk State Agricultural Academy. 1, 55-61, (2018)

2. A.A. Golovin, A.A. Golovin, M.A. Parkhomchuk Proceedings of the 30th International Business Information Management Association Conference, Spain Madrid, pp. 1447-1454 (2017)

3. D. Zyukin, O. Svyatova, E.Zolotareva, A. Bystritskaya, A. Alyokhina (2020). Amazonia Investiga. 9(25), 461-470.

4. D.A. Zyukin, O.N. Pronskaya, O.V. Svyatova, A.A. Golovin, O.V. Pshenichnikova, O.V. Petrushina Revista de la universidad del Zulia. 32, 87-101, (2021).

5. A. Brausmann, L. Bretschger European Economic Review. 108, 1-19, (2018). 